\title{
The Impact of Cultural Organization to the Public Service of Selected Community Organization in Nagcarlan, Laguna, Philippines
}

\author{
Elymar A. Pascual, Maria Gella M. Perez, \\ Melody C. Barja, Margarita C. Bugia, Jr. \\ elymarpascual@rocketmail.com \\ Department of Education, Nagcarlan, Laguna, Philippines, 4002
}

\begin{abstract}
This study focused on finding out whether the cultural organization has a significant relationship to the public service of selected sangguniang barangay in Nagcaralan, Laguna, Philippines. Out of 52 barangays, three barangays were selected - Sabang, Yukos, and Talangan. The survey questions were distributed to the barangay officials as well as to the people in their area - twenty in each barangay, sixty in all. It was discovered that Brgy. Sabang has a moderate level of commitment, satisfaction, and personal and professional growth. It is the same with Brgy. Yukos which has a moderate level of public service in all indicators. Brgy. Talangan has a high level of public service. In terms of organizational culture, it was found that the perception of the people in Brgy. Sabang on the cultural organization of their sangguniang barangay is collectivism, the officials are far from ruling as well as the people, fatalism is practiced, and the way of leadership is feminine. In Yukos, it is collectivism, far from ruling, aggressivism, and feminism. On the other hand, in Talangan, it is collectivism, far from ruling, fatalism, and masculine. Using the t-test for independent variables, it was found that the most significant relevant public service was the masculine/feminine leadership culture, and this was confirmed by p-values $(0.02,0.02,0.03$, and 0.00$)$ that were lower than the alpha of 0.05 . In addition, distance from the leader also affects the personal growth of the officials of the sangguniang barangay (p-value 0.04). Eventually, the writers suggested that officials of sangguniang barangay, as well as local government officials, hold seminars, workshops, or symposiums regarding masculine and feminine culture in an organization, and other related topics. The authors also made a suggestion for young people and future researchers.
\end{abstract}

Keywords: individualism; collectivism; power distance; uncertainty avoidance; masculinity; femininity; commitment

\section{Introduction}

This chapter contains the introduction, the origin of the topic, background information, and other important details relevant to the developed research.

\section{Introduction}

""The leader lives with the people,

to know their problems;

The leader lives with God, to solve them".

\section{-John C. Maxwell}

Leadership is the process of social influence in which a person recruits or solicits the response, help, and patronage of another person to perform a common task. The person who leads or leads is called a leader, a person who is also considered to be the representative of a group of people. A country can be ruled by a 
president or a king and queen. Examples of countries led by a president are the Philippines, America, and China. Examples of countries ruled by King and queen are the United Kingdom in Europe, Nepal and Thailand.

In different countries around the world, different cultures can be seen and learned about. Culture is the unified practice of a group at a particular time. This includes tradition, practices, procedures, and terminology. It does not change quickly. It is stated that things do not change rapidly since cultures evolve over time and a new generation emerges. This gives one a sense of belonging and makes one proud of their country.

A country is made up of various organizations. An organization is one that is well-organized, has a strong leader, and has come to a consensus. It also has the ability to be disciplined. Smart leadership is responsible for the formation of an organization. The members and leaders are the people who make it successful and productive. Discipline and responsibility are necessary for organizations to function efficiently, regardless of where the leader works and would be the law within the organization.

Different leadership styles can be found in many countries across the world. One of them is the cultural organization. Cultural groups have agreed upon or practiced practices within the organization. Many comrades follow it, even though it is not formally taught to them, or as if it had been inscribed on them.

There are 7,107 islands in the Philippines. It has a president in authority, and currently it is $\mathrm{Mr}$. Rodrigo Duterte there. As president-elect, he is now based at Malacanang. The Philippines is made up of several organizations that each safeguard and handle a certain concern. In the Philippines, the barangay is the smallest unit of government. Here, the land is separated into regions. The province of Laguna is part of Region 4A-CALABARZON, which includes the municipality of Nagcarlan. There are 52 barangays in this area. Specifically, brgy. Sabang, yukos, and talangan are some of the most popular foods in the Philippines. The Sangguniang Barangay is the governing body of the barangays. It's headed by a captain.

Other factors, such as the season and the time to focus more on leadership, will invariably have an impact on leadership. Therea are variety of factors that can influence each member of the Sangguniang Barangay's public service, which might lead to them losing interest in serving as a role model for the community. What variables, in your opinion, can affect the public service of Sangguniang Barangay? Does the cultural organization have an effect on the public service of the Sangguniang Barangay?

\subsection{Background}

Republic Act No. 7160, also known as "An Act providing for a Local Government Code of 1991," established the existence of a Sangguniang barangay in every municipality in the Philippines. According to Article 10, Section 2, the declaration of state laws, the division of territory, and state power must be correct and meaningful local autonomy in order for them to achieve full change as self-reliant communities and become a more effective partner in attaining the state's aspiration. Until the end, the state should establish a more active and accountable local government structure based on the decentralization process, with power, authority, responsibility, and necessity for the local government. According to Article 10, Section 4, this law shall apply to all provinces, cities, municipalities, barangays, and other political divisions.

The municipality of Nagcarlan in the Province of Laguna was selected as the site for this study, which has 52 barangays. This study would only be undertaken in three barangays, according to the researchers. Barangay Yukos, barangay Sabang, and barangay Talangan are the three barangays selected.

\subsection{Theoretical Framework}

Four characteristics of cultural appreciation can be found in the book Organizational Behavior and Management by Ivancevich and Matteson (2005). 
Table 1. Cultural values

\begin{tabular}{|l|l|l|l|l|}
\hline \multicolumn{5}{|c|}{ Hofstede's Dimensions } \\
Region/ & $\begin{array}{l}\text { Individualism- } \\
\text { Collectivism }\end{array}$ & Power Distance & $\begin{array}{l}\text { Uncertainty } \\
\text { Avoidance }\end{array}$ & $\begin{array}{l}\text { Masculinity- } \\
\text { Femininity }\end{array}$ \\
\hline North America (USA) & Individualism & Low & Medium & Masculine \\
\hline Japan & Collectivism & High and low & High & $\begin{array}{l}\text { Masculine and } \\
\text { feminine }\end{array}$ \\
\hline Europe & Individualism & Low/medium & Low/medium & Masculine \\
\hline $\begin{array}{l}\text { Anglo Germanic West } \\
\text { Slavic and West Urgic }\end{array}$ & Medium individualism & Low & Medium/low & $\begin{array}{l}\text { Medium/ high } \\
\text { masculine }\end{array}$ \\
\hline Near Eastern Balkanic & Collectivism & High & High & Medium masculine \\
\hline Nordic & $\begin{array}{l}\text { Medium/high } \\
\text { individualism }\end{array}$ & Low & Low/medium & Feminine \\
\hline Latin Europe & $\begin{array}{l}\text { Medium/high } \\
\text { individualism }\end{array}$ & High & High & Medium masculine \\
\hline East Slavic & Collectivism & Low & Medium & Masculine \\
\hline China & Collectivism & Low & Low & $\begin{array}{l}\text { Masculine and } \\
\text { Feminine }\end{array}$ \\
\hline Africa & Collectivism & High & High & Feminine \\
\hline Latin America & Collectivism & High & Masculine \\
\hline
\end{tabular}

The table shows the leadership cultures observed in some countries in the world. Individualism is the culture that has been applied to them in North America (USA), which means that they are better equipped to work alone. They also have a close power distance, and their uncertainty avoidance is a blend of Aggressivism and Fatalism. The leader is focused on growth because the dominating culture is Masculine.

Collectivism is more prominent in Japan, which means they like to work together rather than alone, and they have a combination of far and close power distance in the culture of power distance. They have a culture of Aggressivism due to their high level of uncertainty avoidance. They also follow a Masculine and Feminine culture, which means their leader is concerned with growth and nurture.

The continent of Europe shows Individualism, close and moderate power distance, low and moderate uncertainty avoidance, and there is a Masculine culture in leadership. Individualism shows that they prefer to work alone or in small groups, and their power distance is both close and far. Their uncertainty avoidance is low and moderate, which means they have a mixture of Aggressivism and Fatalism. They implement a Masculine culture that focuses on growth.

On the other hand, the Anglo Germanic West Slavic and West Urgic communities have a culture of Moderate Individualism, which states that they are better off working alone. Their power distance is close. This group exhibits a blend of Aggressivism and Fatalism of Uncertainty Avoidance in some areas, but just Fatalism in others. In some parts of the area, there is a combination of Masculine and Feminine cultures that are focused on growth and nurture, while in others, there is a strong Masculine culture that is focused on growth.

The Near Eastern Volcanic Area enforces the concept of collectivism in which leaders collectively perform a task. Their power distance is far. The uncertainty avoidance that prevails in this country is fatalism. Also, a moderate masculine culture exists in this country.

The Nordic countries have both a moderate and a high level of individualism. They are in close in terms of power distance. Their uncertainty avoidance is fatalism, and is sometimes a combined concept of aggressivism and fatalism. Feminine culture prevails in this country. It denotes that the country's leader is dedicated to the welfare of its people.

Individualism concepts ranging from moderate to high are prevalent in Latin Europe. This country has a far power distance. The uncertainty avoidance of this country is aggressivism. A moderate culture of masculine is the dominant leadership style. It simply signifies that the leadership is focused on growth but not certainly on depth. 
In the East Slavic countries, collectivism prevails. There is a close power distance and integrated concepts of aggressivism and fatalism, which is the undermining uncertainty avoidance. Masculine is the culture demonstrated by the leader. This country is focused on growth.

You will notice that in China's country, they have a system of collectivism in which they work together and have a desire to take each other's ideas. The power distance is as close as its uncertainty avoidance, while this country prevails the Masculine and Feminine cultures, meaning they are centered on growth, even in nurture.

The Africa is next, which also demonstrates Collectivism, while others want each individual to help. However, the power distance is far or distant. It is also far in terms of uncertainty avoidance. This country is also centered on feminine culture, which emphasizes the importance of nurturing above growth.

Finally, a Latin American country exhibits Collectivism with the same goal of seeking assistance from others. They have a far powe distance, as well as in terms of uncertainty avoidance. They also aimed to prevail in the development of nurture because they were centered on Masculine culture.

\subsection{Conceptual Framework}

IV

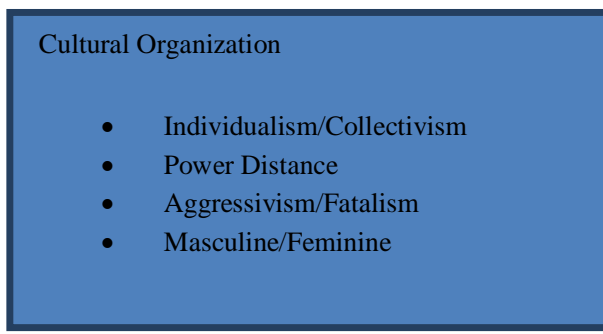

DV

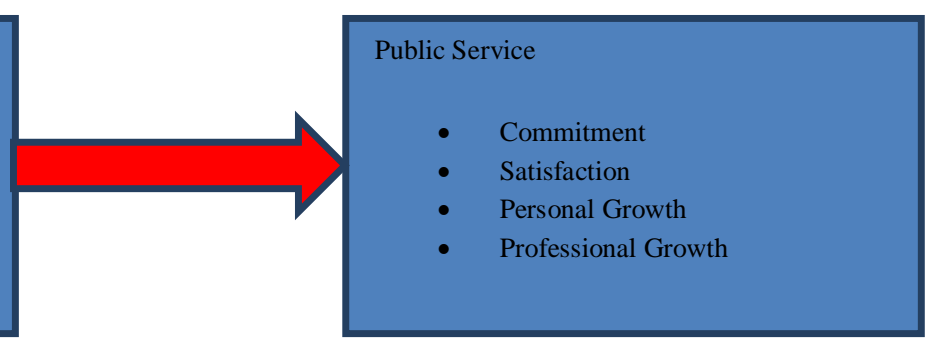

Fig. 1. Paradigm of the study

The box on the right shows the independent variables and is entitled cultural organization. The cultural organization includes indicators of Individualism/Collectivism, Power Distance, Aggressivism/Fatalism/ and Masculine/Feminine.

The left box shows the dependent variable and is entitled to Public Service. It includes indicators of the Commission, Satispace, Personal Growth, and Professional Growth.

These two variables are connected by an arrow, which shows the effect of an independent variable on the dependent variables.

\subsection{Statement of the Problem}

The focus of this study is to determine the impact of the cultural organization on the public service of the selected sangguniang barangay in Nagcarlan, Laguna.

In particular, the researchers want to know the answers to the following questions:

- What is the level of public service of the selected sangguniang barangay in Nagcarlan to the following indicators:
a. Commitment;
b. Satisfaction;
c. Personal Growth;
d. Professional Growth?

- What is the perception of the selected sangguniang barangay in Nagcarlan to their cultural organization in terms of thefollowing indicators: 
a. Individualism/Collectivism;

b. Power Distance;

c. Aggresivism/Fatalism; and

d. Masculine/Feminine?; and

- Does the cultural organization have a significant impact on the public service of the selected sangguniang barangay in Nagcarlan?

\subsection{Hypothesis}

The tentative solution to the problem presented at the beginning of this research is:

The cultural organization has no significant impact on the public service of the selected sangguniang barangay in Nagcarlan, Laguna.

\subsection{Significance of the Study}

It is important to know the importance of this study to the following groups of people:

1. Sangguniang barangay- this study will shed out the culture that officials apply for their work.

2. Sangguniang kabataan- this research will aid future leaders in determining the suitable culture to employ, as it will affect their leadership effectiveness.

3. Students- this study will help the students to fully understand the working culture of the officials of their sangguniang barangay.

4. High Officials- this study will inform senior authorities about the work culture of barangay sangguniang officials, allowing them to determine which project or step should be kept for barangay sangguniang officials.

5. Future Researcher- this study will challenge future researchers on how they can further develop this study.

\subsection{Scope and Limitation of the Study}

In the study conducted, the researchers gathered data and information in Nagcarlan, Laguna. Their research revolved around several barangays specifically in Bgy. Sabang, Brgy. Yukos and Brgy. Talangan. The researchers gave survey questions to twenty people per barangay with a total of sixty people. Their research was given meaning by the facts and information they obtained. This research takes up their time and effort. They were able to find the information in the time provided.

\subsection{Definition of Terms}

The terms used in this study, as well as their definitions, are listed below.

- Cultural Organization - Culture is the unified practice of a group at a particular time. This includes traditions, practices, methods and terminology. It does not change quickly. An organization is an organization with order, with leadership, with consensus. It also has disciplines to follow. In this paper, cultural organization is practices agreed upon or practiced in an organization. It is followed by many although it is not formally introduced to the comrades, or followed as if engraved in them.

- Public Service- According to Meriam Webster, public service is the mobilization of the willing to help rather than the salary. It is also working in government and is done by "public servants". But the definition given in the study is that public service is the provision of service to the government and to the people. 
- Individualism- According to Webster, Individualism is the ability of a person to act independently or to be "independent". But in the writing of this research, individualism is the emphasis on working separately but towards a common goal. Individualism was measured by survey question, group one, category A.

- Collectivism- According to Meriam Webster, Collectivism is the Economic system in which the government owns a business. But here, it means giving importance to labor through collective action. This was measured with the help of survey question, group one, category A.

- Power Distance - This is the general term for the distance between the leaders and the led. The distance can be near or far. When closed, it is considered a flat organization. When far away, it is hierarchical. In this paper, the distance to the leader refers to the relationship of the leaders to each other and to those they lead, whether they have a close or distant relationship. When far away, it doesn't mean emotionally far away, but a culture that shows deep professionalism. It was measured in this study by a survey question, group one, category B.

- Aggresivism - This is one of the uncertainty avoidances of cultural organization. Its counterpart is fatalism. Aggresivism is the behavior of trying the unfamiliar. As of this study, aggresivism is entering into projects that seem difficult but want to try. This variable was measured by survey question, group one, category $\mathrm{C}$.

- Fatalism- Fatalism, according to Meriam Webster, is the belief that events are predetermined and cannot be changed. Fatalism, on the other hand, is valuing the familiar and avoiding moderns that may bring doubt or anxiety in this study. The survey question, group one, category $\mathrm{C}$, was used to assess fatalism.

- Masculine- Masculine, according to Webster's Dictionary, is the possession of a man's character. However, we can see from this study that the meaning is to have a leading individual, or someone who is focused on the constituency's growth. It was also assessed by a survey question in category D, group one.

- Feminine- Feminine, according to Webster's Dictionary, is a woman's identity. And, to write in this study, Feminine is the presence of a powerful woman, or one who is concerned with the welfare of her constituents. This was determined using a survey question from group one, category D.

- Commitment- Commitment, according to Meriam Webster, is the dedication to do something. It is also a person's habit of working hard or supporting something. As a result, it might be considered to be honest and dedicated to duty. Group two, category A, of the survey question measured commitment as well.

- Satisfaction- It is the factor that defines an individual, according to Webster's Dictionary. Internal rewards are also available to officers. It was likewise measured using a survey question, group two, category B, as was the case with the others.

- Personal Growth- Personal growth, according to Wikipedia, refers to how you think about yourself and your life. In this study, however, the focus is on an individual's development as a result of his interactions with other people. This was measured once more utilizing group two, category $\mathrm{C}$ of the survey question.

- Professional Growth- Professional growth, according to Wikipedia, is the ability to accumulate sufficient evidence, such as an academic degree for work allocated to a particular course, meetings, and informal learning abilities that can be demonstrated in practice. However, according to the text in this study, it is an individual's professional growth or that which is related to the work he performs. It was determined by the use of a survey question from group two, category D.

\section{Related Studies}

This chapter includes previous studies and published writings, it serves as the basis for analyzing, 
comparing, and contrasting the past with the present study.

\subsection{Individualism and Collectivism}

An individual is a person who is able to stand in front of many people. He is capable of upholding the things or belief that he knows are right. According to (n.d.), "Individualism is a political and social philosophy that emphasizes the moral values of an individual".

Individualism also shows human selfishness which causes them to pay attention to those who are only close to them (De Tocqueville, 1805). But what can individualism do for our society?

Individualism can help society because it shows who we are and it allows man to express himself freely. It also enables us to value ourselves as individuals without simply relying on other people's opinions (Kando, 2011).

This kind of philosophy can become the culture of leaders and workers so that they can further improve their work. As stated in the previous passages, some people choose to be alone in activities and decisions that shows Individualism.

High display of individualism means poor connection to non-part of the family you consider (Hofstede, 2010)

But according to Landauer and Rowlands (2001), Individualism is ignored because it is only a tool to form a group. And here it enters the concept of Collectivism or cooperation with other people.

Landauer and Rowlands (2001) also says that, Collectivism also means giving value to the group and it can be in a tribe, family, nation, race, gender, and other groups or organizations.

It is important to know about Collectivism because it is the opposite of individualism. Collectivism is a political belief that states that a person must work with other people in order to have the same idea in a group. It emphasizes the value of the group beyond just the individual (Jones, 2011).

Collectivism shows that the person must be loyal to the group he or she belongs to, and in return the group will dictate the total interest (Hofstede, 2010)

Cultural collectivism is connected to an organization or group. In some cases, it becomes a habit for leaders and workers to work with other people to speed up a project and decision making.

\subsection{Power Distance}

Within a group or organization, there may be superiority or someone ahead of everything. And here it enters the concept of power distance or distance to the ruler.

The power distance shows the unequal dealings that occurs and are accepted between the powerful man and the powerless man. The existence of a high-Power Distance Index (PDI) shows that society accepts the existence of unequal power. On the other hand, having a low PDI shows that power in a group is equally expressed and does not accept inequality of power (Hofstede, 2010).

\subsection{Aggresivism and Fatalism}

Another bases of work culture and leadership is the so-called uncertainty avoidance and it has a type - the aggresivism and fatalism.

According to Todd (2015), fatalism describes that no human habits is free. It is grouped into two; the first is logical fatalism, and the second is the theological fatalism.

According to Carmody (2002), Theological fatalism shows that our lives are under the control of more powerful beings. Likewise, the course of our fate is already revealed to us before we are born.

Whatever you do, the same thing you did will happen to you. It is also said that when you do not have free will, our lives will eventually be dictated by those around us, so that our beliefs and desires will not 
affect those around us, and if so, no matter what we do, it will also happen to us (Clark, 1998).

On the other hand, there is another type of human habit that affects his work and activities. This is Aggresivism.

According to Moyer (1976), aggresivism can be verbal or symbolic, but violence shows human aggresivism in the physical realm

The violence caused by a person's aggressiveness is acknowledged by Gabbey and Jewell. According to Gabbey and Jewel (2016), aggressive behavior can pose physical or emotional danger to others.

According to Collins (2017), a person who is aggressive in what he does may act violently because he wants to finish something.

The researchers chose these passages because they believed that these would help their study.

\subsection{Masculine and Feminine}

According to history, "Datu" was the name of the leader of the barangay. The Datu serves as the legislator, executive, and judge. He is also considered as the military leader in the community. In choosing a Datu, a person's strength, courage, and fortitude are considered to ensure his or her ability to defend his or her barangay from enemies. (Jetsetter, 2014)

According to Comelec Commissioner Rowena Guanzon who is the head of the Comelec's GAD, they want gender equality so they encourage women to run so that $50 \%$ of government officials will be men and women. (Aguilon E., 2017)

According to Gabriela's fighting leader, it is not enough to simply increase the number of elected women in the barangay. He said it is more important to choose the candidate, whether male or female, who has a clear platform for promoting gender equality. (Gabriela, 2013)

\subsection{Commitment}

It is the duty of the Barangay Captain to ensure the distribution of public services, conduct annual barangy games and impoe the laws and ordinances applicable to the barangay. Also, it I the duty of the Sangguniang Pambarangay to assist in the conduct and organization of trades within the barangay and to perform other duties imposed on their barangay head. (Resident Patriot, 2015)

The Sangguniang Pambarangay of Dangoy together with the Treasurer and the Secretary with a total of ten people, even if none of them use and drive illicit drugs must see their support for the President's program against illegal drugs through voluntarily making the Oath of Commitment with their signature. (https://www.facebook.com)

\subsection{Satisfaction}

The barangay has at leas $55 \%$ of the total annual income for personal service - this includes the salary allocated for elected officials and corresponding staff such as the barangay treasurer and secretary. (Mendiola, 2013)

Ordinance No. 001 Series of 2010 Standardized Barangay Official Welfare Benefits aims to provide benefits to barangay officials who complete three consecutive terms. (Butch Quejada, 2010)

House Bill 4712, introduced by Las Piñas Representative Mark Villar, states that $尹 100,000$ retirement benefits will be provided for Barangay Officials, $\mathrm{P} 80,000$ for Sangguniang Barangay Members and P50,000 for other officials such as Barangay Tanod, members of the Lupong Tagpamayapa, Barangay Heath Workers and Barangay Day Care Workers. This is only for those who have served 11 years in service and have passed away at 60 -years old. It will be received by all barangay officials who have died in the service, had a permanent disability even before reaching 60 years of age and length of service. (https://www.remate.ph) 


\subsection{Personal Growth}

Personal Growth means, you think and look at yourself, the life you have. Perhaps there is a chance that you are feeling inadequate and what else can be honed in yourself. You begin to organize yourself. How you look at things around you is what you have witnessed and believed. A person's identity still changes based on what you are, where you excel, what talent you have, and what you desire in life.

Personal Growth is a long process. Man has the capacity to learn and organize himself and has the ability to act on what he has learned in each part of the experiences. Personal Growth can be seen in the workplace as well as in a relationship. Personal Growth has various components, including responsibility, learning habits, and an individual's actions or attitudes. You strive to train yourself as an individual which can result in improved workplace relationships as well as your health. (shapeofyourfuture.com)

Perhaps the most important things we have learned is that in the process of achieving success there is no perfect element that will describe what is the path to a person's personal success. We 11 have our own dreams and priorities in life which means we have different abilities and attitudes that make us feel better.

\subsection{Professional Growth}

Professional Growth is a new radical type of growth of being a city, driven by the desire to survive and not to prosper. Advice and service to other people, for a direct and definite compensation, entirely separate from the expectation of other business achievement.

According to Wikipedia, Professional Growth is learning to gather sufficient evidence such as an academic degree for work assigned to a chosen course, meetings, informal learning skills that can be seen in practice. There are variations on the path to Professional Growth such as interviewing, training, communication training, lesson learning, teaching, reflective supervision, and technical assistance. (http://en.wikipedia.org/wiki/Professional_development)

In some cultures, the term "professional" is used as a phrase to describe a particular social stratum of educated and salaried workers who enjoy broad work autonomy and typically participated in creative and thoughtful challenging work.

Because of the personal and confidential (secret) nature of many professional services, which require a large percentage of trust in them, most professionals are subjected to strict codes of conduct that impose strict moral obligations and ethics. (http://www.eqi.org/pg.htm)

\section{Methodology}

This part of the study refers to the research design, the interviewee in the study, the instrument used, the data collection procedure, and the statistical treatment.

\subsection{Research Design}

This study used an experimental design in conducting the research. According to Blay (2013), design is used to determine the cause-and-effect relationship. Researchers who will use this type of method may go beyond just a simple description. For this study, the researchers wanted to know the impact of cultural Organization on the Public Service of Barangay Councils. This is why this study is experimental because the researchers want to perform specific work that may or many not affect the behavior of the interviewees.

\subsection{Data Gathering}

The flowchart on the next page shows the step-by-step process of finding an answer to the problems 
presented in the early part of the study.

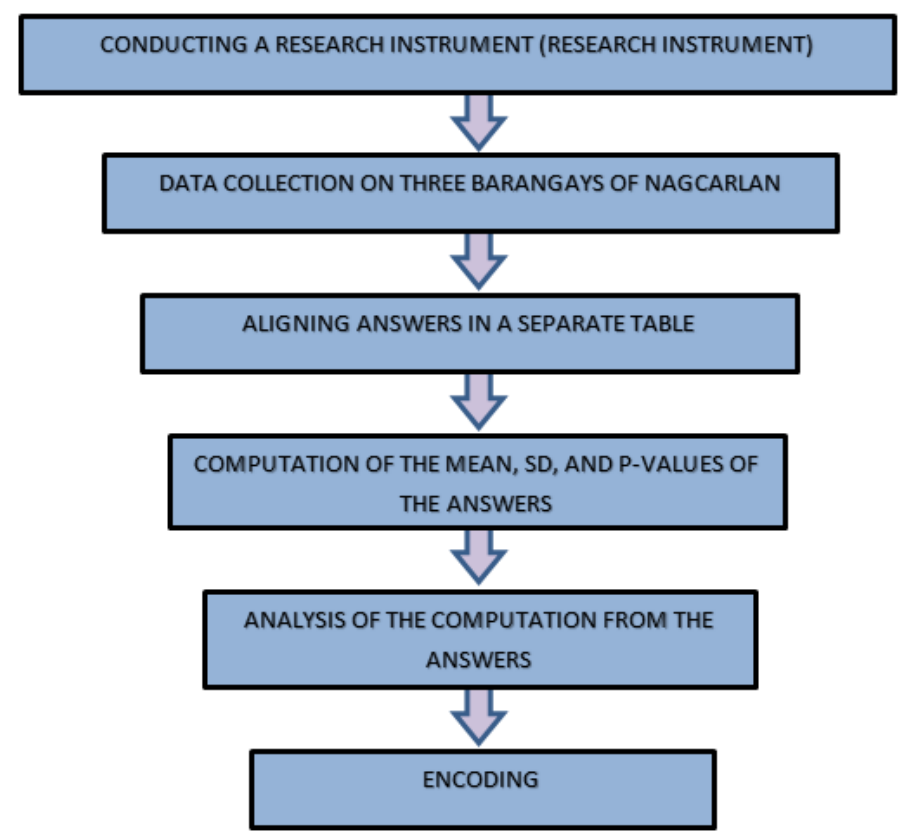

Fig. 2. Flowchart of the data collection procedure

\subsection{Population}

The respondents in each barangay can be seen in the succeeding table.

Table 2. Response of each barangay

\begin{tabular}{|c|c|c|c|}
\hline Barangay & $\begin{array}{c}\text { Number of Sangguniang } \\
\text { Barangays Responded }\end{array}$ & $\begin{array}{c}\text { Number of Citizen } \\
\text { Responded }\end{array}$ & Total \\
\hline Talangan & 6 & 14 & 20 \\
\hline Yukos & 1 & 19 & 20 \\
\hline Sabang & 1 & 19 & 20 \\
\hline Total & 8 & 52 & 60 \\
\hline
\end{tabular}

It shows the number of Sangguniang Barangay and the number of people who responded to the survey regarding the practices carried out by barangay officials

\subsection{Research Instrument}

The research uses two questionnaire investigations.

- Cultural Organization - it consists of four categories; Individualism and Collectivism, Distance from the leaders, Aggressivism, and Fatalism, and the Feminist and Masculine which will help to better understand the content of the study. People interviewed rated themselves based on the indicator on a scale from 1 to $4 ; 1$ serves as the lowest level while 4 serves as the highest level. 
- $\quad$ Public Service - the survey questionnaire assess the application of various public services. It consists of commitment, satisfaction, personal development, and professional development. The researchers created this questionnaire to calculate how a public service is conducted or operated. The people interviewed evaluated the application on a scale from 1 to 4 . The equivalent of each scale is as follows;

$$
\begin{aligned}
& 1 \text { - Not Noticed } \\
& 2 \text { - Rarely Noticed } \\
& 3 \text { - Many Times Noticed } \\
& \text { 4-Always Noticed }
\end{aligned}
$$

\subsection{Statistical Treatment}

To answer the specific questions in this study, they following statistical treatment were used:

For Cultural Organization - simple mean and SD

For Public Service - simple mean and SD same sample

For the Impact of Cultural Organization and Public Service of Barangay Officials - t-test for the

\section{Presentation, Analysis and Interpretation of Data}

This section contains the presentation of the data obtained, the analysis of them, and the

\begin{tabular}{|c|c|c|c|c|c|c|c|c|c|c|c|c|}
\hline \multirow[t]{2}{*}{ Barangay } & \multicolumn{3}{|c|}{ Commitment } & \multicolumn{3}{|c|}{ Satisfaction } & \multicolumn{3}{|c|}{ Personal Growth } & \multicolumn{3}{|c|}{ Professional Growth } \\
\hline & $\mathrm{Mn}$ & $\mathrm{Sd}$ & $\begin{array}{l}\text { Intepreta- } \\
\text { tion }\end{array}$ & $\mathrm{Mn}$ & $\mathrm{Sd}$ & $\begin{array}{l}\text { Intepreta- } \\
\text { tion }\end{array}$ & Mn & $\mathrm{Sd}$ & $\begin{array}{l}\text { Intepreta- } \\
\text { tion }\end{array}$ & $\mathrm{Mn}$ & $\mathrm{Sd}$ & $\begin{array}{l}\text { Intepreta- } \\
\text { tion }\end{array}$ \\
\hline Sabang & 2.28 & 0.73 & Moderate & 2.28 & 0.86 & Moderate & 2.03 & 0.62 & Moderate & 2.36 & 0.65 & Moderate \\
\hline Yukos & 2.53 & 0.78 & Moderate & 2.42 & 0.85 & Moderate & 2.34 & 0.79 & Moderate & 2.16 & 0.62 & Moderate \\
\hline Talangan & 3.12 & 0.20 & High & 2.89 & 0.23 & High & 2.73 & 0.39 & High & 3.32 & 0.31 & High \\
\hline Average & 2.64 & 0.57 & High & 2.53 & 0.65 & Moderate & 2.37 & 0.60 & Moderate & 2.61 & 0.53 & High \\
\hline
\end{tabular}
interpretation of each found in the records.

\subsection{Public Service}

Table 3. Public service mean level of community leaders

Legend: 3.21-4.00 - Highest level

2.61-3.20 - High level

1.81-2.60 - Moderate level

1.00-1.80 - Low level

The table above shows the level of public service of the selected barangay council of Nagcarlan. In commitment, it can be seen that Talangan has the highest level (3.12). The average of the three sangguniang barangays is 2.64 with a standard deviation of 0.57 . This says that the level of commitment of the threebarangay council is at a high level. The standard deviation of 0.57 indicates that their answers are close together.

Meanwhile for Satisfaction, it can be noted that Talangan still has the highest level (2.89). It can also be seen that it has an average of 2.53 and standard deviation of 0.65 . It says that the level of satisfaction of the three barangays is at a moderate level. A standard deviation of 0.65 means their answers are close or compatible.

For Personal Growth, Talangan still has the highest level (2.73) followed by Yukos (2.34) followed by Sabang (2.03). The three barangays have an average of 2.37 and standard deviation of 0.60 . This means 
that the level of Personal Growth of the three said barangays is at a moderate level. While its standard deviation says their answer is close or compatible.

Lastly Professional Growth, Talangan still has the highest level (3.32) followed by Sabang (2.36) followed by Yukos (2.16). The said barangays have an average of 2.61 and standard deviation of 0.53 . This is to say that the level of Professional Growth of the three barangays is at a high level. While the standard deviation says that their answers are close or compatible.

All this proves that each barangay has a consistent answer based on Commitment, Satisfaction, Personal Growth, and Professional Growth. It will also be noted that Talangan always has the highest level compared to the other two barangays.

\subsection{Cultural Organization}

It is noted that the mean of Talangan and Yukos (2.43) are similar at moderate level while Sabang (2.23) is different but also at moderate level. The three barangays have an average of 2.36 and standard deviation of 0.30 . This simply means that the Sangguniang Barangay of the three barangays is in Collectivism.

Table 4. Cultural organization awareness level of community leaders

\begin{tabular}{|c|c|c|c|c|c|c|c|c|c|c|c|c|}
\hline \multirow[t]{2}{*}{ Barangay } & \multicolumn{3}{|c|}{ Individualism/Collectivism } & \multicolumn{3}{|c|}{ Power Distance } & \multicolumn{3}{|c|}{ Aggresivisim/Fatalism } & \multicolumn{3}{|c|}{ Masculine/Feminine } \\
\hline & $\mathrm{Mn}$ & $\mathrm{Sd}$ & $\begin{array}{l}\text { Interpreta- } \\
\text { tion } \\
\text { (Culture) }\end{array}$ & $\mathrm{Mn}$ & $\mathrm{Sd}$ & $\begin{array}{l}\text { Interpreta- } \\
\text { tion } \\
\text { (Culture) }\end{array}$ & $\mathrm{Mn}$ & $\mathrm{Sd}$ & $\begin{array}{l}\text { Interpreta- } \\
\text { tion (Culture) }\end{array}$ & Mn & $\mathrm{Sd}$ & $\begin{array}{l}\text { Interpreta- } \\
\text { tion } \\
\text { (Culture) }\end{array}$ \\
\hline Sabang & 2.23 & 0.39 & $\begin{array}{c}\text { Moderate } \\
\text { (Collectivis } \\
\mathrm{m})\end{array}$ & 2.55 & 0.32 & $\begin{array}{c}\text { Moderate } \\
\text { (Low Power } \\
\text { Distance) }\end{array}$ & 2.57 & 0.24 & $\begin{array}{l}\text { Moderate } \\
\text { (Fatalism) }\end{array}$ & 2.53 & 0.38 & $\begin{array}{l}\text { Moderate } \\
\text { (Feminine) }\end{array}$ \\
\hline Yucos & 2.43 & 0.30 & $\begin{array}{c}\text { Moderate } \\
\text { (Collecti- } \\
\text { vism) }\end{array}$ & 2.47 & 0.28 & $\begin{array}{c}\text { Moderate } \\
\text { (Low Power } \\
\text { Distance) }\end{array}$ & 2.79 & 0.38 & $\begin{array}{l}\text { Moderate } \\
\text { (Aggresi- } \\
\text { vism) }\end{array}$ & 2.43 & 0.43 & $\begin{array}{l}\text { Moderate } \\
\text { (Feminine) }\end{array}$ \\
\hline Talangan & 2.43 & 0.22 & $\begin{array}{l}\text { Moderate } \\
\text { (Collecti- } \\
\text { vism) }\end{array}$ & 2.57 & 0.16 & $\begin{array}{c}\text { Moderate } \\
\text { (Low Power } \\
\text { Distance) }\end{array}$ & 2.48 & 0.17 & $\begin{array}{l}\text { Moderate } \\
\text { (Fatalism) }\end{array}$ & 2.83 & 0.19 & $\begin{array}{c}\text { High } \\
\text { (Masculine) }\end{array}$ \\
\hline Average & 2.36 & 0.09 & $\begin{array}{l}\text { Moderate } \\
\text { (Collecti- } \\
\text { vism) }\end{array}$ & 2.53 & 0.08 & $\begin{array}{c}\text { Moderate } \\
\text { (Low Power } \\
\text { Distance) }\end{array}$ & 2.61 & 0.11 & $\begin{array}{l}\text { Moderate } \\
\text { (Aggresi- } \\
\text { vism) }\end{array}$ & 2.6 & 0.13 & $\begin{array}{l}\text { Moderate } \\
\text { (Feminine) }\end{array}$ \\
\hline
\end{tabular}

Legend: 3.21-4.00 - Highest level

2.61-3.20 - High level

1.81-2.60 - Moderate level

$1.00-1.80$ - Low level

The mean of each can be seen to be different. Talangan has 2.57 mean, Sabang has 2.55 mean and Yukos has 2.47 mean. Each barangay is at a moderate level. The average of the three barangay sangguniang is 2.53 and standard deviation is 0.25 . This says their leadership differs in many ways.

In terms of Aggresivism/Fatalism, Yukos is the highest compared to the four, because it has 2.79 mean at a high level. Next is Sabang (2.57) which is at a moderate level and finally Talangan (2.48) which is also at a moderate level. Its average is 2.61 and standard deviation is 0.26 which means that the general culture in the three sangguniang barangays is Aggressivism.

And lastly, Talangan can be seen leading with mean of 2.83 and it is at high level. Sabang (2.53) and 
Yukos (2.43) is at moderate level. They have an average of 2.60 and standard deviation of 0.33 which says that the general culture in the three barangays is Feminine.

The above shows different results per mean and standard deviation. This happens more often than in the first record. It also concludes the kind of leadership there is in the said barangays.

\subsection{Impact of Cultural Organization on Public Service}

It can be seen in the table below, in the Commitment column, that the Cultural Organizations such as Individualism/Collectivism, Power Distance and Aggressivism/Fatalism have a high P-value greater than the alpha value of 0.05 . Consequently, these variables do not directly affect the Commitment. It wants to convey that even if the officials of the sanguniang barangay work alone (individually) or collectively, it will not affect their Commitment to work. Also, the concept of Power Distance does not fully affect the Commitment of officers. According to it, even if the officer wants to create changes (aggression) or obedience to destiny (fatalism) it will not fully affect the officer's commitment to his work. On the other hand, the Feminine and Masculine has a P-value of 0.02, and this is lower than the alpha value of 0.05. This shows that Feminine and Masculine have a direct relationship with the Commitment of the barangay council in his work. As a result, certain activities of women and men may affect their Commitment to work. Examples of this are household chores in women. Perhaps because the woman is also a mother in her family, they have to finish household chores first before going to work.

Table 5. Significant effect of cultural organization to public service

\begin{tabular}{|l|l|c|c|}
\hline \multicolumn{1}{|c|}{ Public Service } & \multicolumn{1}{|c|}{ Cultural Organization } & P-value & Significance \\
\hline Commitment & Individualism/Collectivism & 0.46 & \\
\hline & Power Distance & 0.24 & 0.87 \\
\hline & Aggresivism/Fatalism & 0.02 & \\
\hline & Masculine/Feminine & 0.29 & \\
\hline Satisfaction & Individualism/Collectivism & 0.59 & \\
\hline & Power Distance & 0.59 & Significant \\
\hline & Aggresivism/Fatalism & 0.02 & \\
\hline Personal Growth & Masculine/Feminine & 0.79 & Significant \\
\hline & Individualism/Collectivism & 0.04 & \\
\hline & Power Distance & 0.08 & Significant \\
\hline & Aggresivism/Fatalism & 0.03 & \\
\hline Professional Growth & Masculine/Feminine & 0.48 & \\
\hline & Individualism/Collectivism & 0.22 & \\
\hline & Power Distance & 0.51 & Significant \\
\hline & Aggresivism/Fatalism & 0.00 & \\
\hline
\end{tabular}

It can also be seen in the table above, in the range of Satisfaction variables, Aggressivism/Fatalism, Power Distance, Individualism/Collectivism have high P-values greater than the Alpha value of 0.05, so these variables appear to have no direct connection to the Satisfaction of the work of the Sangguniang barangays. This shows that even if the officers work alone or together it still will not affect their Satisfaction with their work. It turns out that Individualism and Collectivism have nothing to do with their contentment in life and the benefit they derive from their work. It also wants to convey that even if each officer has a Power Distance, it will not affect the Satisfaction of their work. Also, the concept of Aggressivism and Fatalism has nothing to do with the Satisfaction of the work of officers. On the other hand, the variable Feminine and Masculine had a low P-value of 0.02 compared to the Alpha value of 0.05 , so it shows that the concept of Feminine and Masculine affects the Satisfaction of officers in their work. It affects because they have the opportunity to work such as promotion, that affects the Satisfaction of the officer, but it is still based on their gender. 
The table above shows that organizational cultural such as individualism/collectivism have no direct impact on personal growth. It has a P-value of 0.79 , which exceeds the expected alpha of 0.05 , so it is said to have no direct impact on the personal growth of the Sangguniang Barangay. Doing a task alone or together is not a measure of personal growth. Also, the record shows that aggressivism and fatalism have no direct impact on public service personal growth. It has a P-value of 0.08 that exceeds the expected alpha so it is said that aggressivism/fatalism have nothing to do with the personal growth of the Sangguniang Barangay. If we investigate, having a new way of leading and following the usual or customary method has no effect on personal growth. The record shows that Power Distance and masculine/feminine in a Sangguniang Barangay have an impact on personal growth. The two mentioned cultural organizations have met the expected alpha which is why it is said that it greatly affects the personal growth of the Sangguniang Barangay. Probably because a masculine and feminine person have their own way to achieve their personal growth. We can also say that the Power Distance is related to personal growth because the closer a member of the Sangguniang Barangay is to the leader, then he can adapt the good ideas and leadership methods of the currently elected. He can use it for his personal growth.

In the table above, it can be seen that individualism/collectivism, power distance and aggressivisim/fatalism, do not directly affect professional growth within the Sangguniang Barangay. The Pvalue of cultural organizations did not meet the expected alpha. The masculine and feminine has a direct impact on professional growth. Its P-value of 0.00 meets the expected alpha. Probably because a masculine person is given more opportunity to be promoted or has a masculine nature in leadership so it is given the opportunity to have professional growth.

\section{Summary of Findings, Conclusions, Recommendations and Reflection}

This section of the paper contains a summary of the data obtained and analyzed, conclusions, recommendations, and reflections of the authors regarding the research conducted.

\subsection{Summary}

The researchers wanted to know the relationship of the Cultural Organization to the Public Service of the barangay council officials. The following are the things that researchers should discover in this study:

- The level of public service of the selected barangay council in Nagcarlan is based on the following indicators:
a. Commitment;
b. Satisfaction;
c. Personal growth;
d. Professional growth

- The perception of the selected barangay council in Nagcarlan in their organizational culture on the following indicators:

a. Individualism/collectivism;

b. Power Distance;

c. Aggressivism/fatalism;

d. Masculine/feminine;

- Significant impact of organizational culture on the public service of the selected barangay council of Nagcarlan.

\subsection{Findings}

Here are the findings of the study:

- The level of public service in the selected barangay council in Nagcarlan with various indicators is: 
a. 2.64 mean (high level) and $0.57 \mathrm{sd}$ for commitment

b. 2.53 mean (mean level) and $0.65 \mathrm{sd}$ for satisfaction

c. 2.37 mean (mean level) and $0.6 \mathrm{sd}$ for personal growth

d. 2.61 mean (high level) and 0.53 in for professional growth

- The perception of the selected barangay council in Nagcarlan in their organizational culture on various indicators is:

a. 2.36 mean (moderate level) and $0.30 \mathrm{sd}$ for individualism/collectivism

b. 2.53 mean (mean level) and $0.25 \mathrm{sd}$ for power distance

c. 2.61 mean (high level) and $0.26 \mathrm{sd}$ for aggressivism/fatalism

d. 2.60 mean (moderate level) and 0.33 sd for masculine/feminine

- The obtained p-values are as follows:

a. 0.46 commitment vs. individualism/collectivism

b. 0.24 commitment vs. Power distance

c. 0.87 commitment vs. aggressivism/fatalism

d. 0.02 commitment vs. masculine/feminine

e. 0.29 satisfaction vs. individualism/collectivism

f. 0.59 satisfaction vs. Power distance

g. 0.59 satisfaction vs. aggressivism/fatalism

h. 0.02 satisfaction vs. masculine/feminine

i. $\quad 0.79$ personal growth vs. individualism/collectivism

j. $\quad 0.04$ personal growth vs. Power distance

k. 0.08 personal growth vs. aggressivism/fatalism

1. 0.03 personal growth vs. masculine/feminine

m. 0.48 professional growth vs. individualism/collectivism

n. 0.22 professional growth vs. Power Distance

o. 0.51 professional growth vs. aggressivism/fatalism

p. $\quad 0.00$ professional growth vs. masculine/feminine

\subsection{Conclusion}

According to the findings in this study, it can be seen that cultural organization has a slight impact on public service. Masculine/feminine affects four indicators of public service. Furthermore, power distance affects the public service indicator of personal growth.

\subsection{Recommendations}

It is a good thing that researchers have a contribution to the people and leaders of Nagcarlan. Therefore, in this part, the Recommendations of the researchers for the Students, Sangguniang Barangay, Sangguniang Kabataan, Senior officials and future researchers are presented.

- Sangguniang Council - It is suggested that masculine and feminine culture be combined in the making of projects and in any work of the sangguniang barangay. This can be done by focusing on simultaneous growth and care in the constituency. Likewise, the power distance of the leader to their constituency should be reduced so that the personal growth of the barangay officials can be further increased. This can be done through the application of their heart and through the visitation of barangay officials.

- Sangguniang Kabataan - As new leaders of our community, it is suggested that they investigate and start practicing a good culture that they can fully use in their leadership. 
- Students- Study the different organizational cultures and also get to know the barangay officials, as well as their projects to find a way to participate in them.

- Senior officials - Senior local government officials can undertake a project or task that can enhance the commitment, satisfaction, personal and professional growth of lower officials.

- Future researchers - To make this research even better, they can increase the scope of the research. It would be better if the 52 barangays in Nagcarlan were given attention.

\subsection{Reflection}

While conducting this research you will realize the things you are witnessing around us. As a youth, you can see the different meanings of the writings on the following page.

In Individualism, one sees the responsibility of a youth or person. Consequently the action alone enters into an individual. But bringing together each individual and giving an idea or collaborating with others can be called Collectivism. Everyone who leads a Sangguniang Barangay or a school and so on can still be called Collectivism. This is needed by every organization because it pays attention to the group not just one individual, everyone's ideas are listened to and not just one. With the increase of leadership in an organization and so on it is inevitable to have a Power Distance. This is where the inequality of dealing with the capable or the powerful comes into play. This happens not only in a Sangguniang Barangay but also in an organization that includes a young person like me. Because of unequal treatment, the power of a leader can be misused. This is where Aggressivism comes in, it can be verbal or gesture that signifies human aggression that can cause physical danger or even emotional. In Fatalism, we can see free will, without which those around us will dictate our actions. Each of us must only have free will so that we can fulfill the desires and not be dictated by others.

In today's era, you often hear the term "gender equality" and in leadership it is practiced as well. It is also often heard in every choice of leader that it is only right that there should be a woman and a man leading a group. These are called Masculine and Feminine. Every leader whether old or young should be "committed" to their work. Commitment is seen in all work; it is the responsibility of each person. Every leader has the right to get Satisfaction or the thing that makes them happy. Here every leader will be happy, especially a young person, to have at least "incentives" for the things they have done for the country. Here you can also feel the Personal Growth as an individual, the growth with one's own abilities as well as the Professional Growth that shows a person's professionalism. daily lives.

Each of these can be seen and inferred by a young person today. For this reason, they witness in their

\section{Acknowledgements}

This study is offered by the researchers to all citizens, especially the executives of the Sangguniang Barangay. It is also for registered youth voters, who already belong among the constituencies of the leader of a barangay. This article contains information about cultural organizations that may affect the public service of a Sangguniang Barangay. It describes indicators that may have a significant impact on public service.

M.C.B

This research is also offered to young people to be open to the kind of leadership their town has. That the service does not end with the election, but rather, it is just the beginning. Likewise, the people have long been open-minded to the concept of government. It not only reflects the culture that is practiced in each barangay but also what kind of leader you have.

M.C.B.J 
This study was dedicated by the researcher to his parents, Flicima M. Perez and Renato M. Perez, to his siblings, Eisser Zairon M. Perez, Randolph M. Perez, and Micaella M. Perez, to his close friends, to his good teachers, and to his beloved school, Talangan Integrated National High School. He also dedicates this victory to the Lord Almighty, who gave him strength and intelligence.

\section{M.G.M.P}

\section{References}

Aguilon, E. (2017). "Konsultasyon sa Iba’t Ibang Grupo para sa Brgy. Elections, sinimulan na ng Comelec".

Carmoody, M. (2002). Fate and Fatalism. www.richmond-philosophy.net/rjp19_carmody.php

Clark, T. W. (1998). www.naturalism.org/hilosophy/free-will/fatalism/determinism-vs-fatalism

Collins. (2017). Definition of Aggressive. https://www.collinsdictionary.com/dictionary/ english/aggressive

De Tocqueville, A.. (1805). Individualism. https://study.com/individualism

Gabbey, E. \& Jewell, T. (2016). Healthline Aggressive Behavior. March 7, 2016. www.healthline.com/health/aggressive-behavior

Gabriela. (2017). "Labanan ang pork sa Barangay Elections, isulong karapatan ng kababaihan-Gabriela". https://gabrielawomensparty. net/content/labanan- ang-pork-sa-barangay-elections-isulong-karapatan- ngkababaihan-gabriela

Hofstede, G. (n.d.) "Cultures and Organizations: Software of the Mind." 2010 . https://www.mindtools.com/pages/article/newLDR_66.htm

Ivancevich, J. M. \& Matteson, M. T. (2005) Organizational Behavior and Management, $6^{\text {th }}$ edition, McGraw- Hill/Irwin Publication, New York

Jones, K. (2001). Collectivism - the opposite of individualism and America. May 13, .https://scienceleadership.org/blog/collectivism_the_opposite_of__individualism_and_america

Jetsetter22. (June 7, 2014). "Ang Pamahalan ng Sinaunang Lipunang Pilipino: Barangay." http://www.slideshare.net/jetsetter22/barangay-35611385

Kando, T. (November 13, 2011). "Individualism”. http://european- americanblog.blogspot.com/?2011 ?04/?some-more-thougts-onindividualism.htm

Landauer, J. \& Rowlands, J. (2001). Importance of Philosophy. www.importance of philosophy.com/Evil_Collectivism.html

Lukes, S. M. (n.d.). Individualism/Politics and Philosophy, https://britannica.com/topic/individualism

Mendiola, R. L.. (October 25, 2013). "Perks of Barangay Officials".

Moyer, K.E. (1976). THE PSYCHOLOGY OF AGGRESSION. https://www.skillsyouneed.com/ps/dealing-with-aggression.html

Oath of Commitment from Barangay Officials of Dangoy. (August 29, 2010).

Resident Patriot. (October 17, 2015). "Mga Tungkulin at Responsibilidad ng mga Elected Government Officials".

Shape of Your Future- Promoting a healthy Lifestyle (Motivation that improves a healthy lifestyle through excercise and nutrition) shapeofyourfuture.com. (n.d.)

Todd, P. (October 8, 2015). Oxford Bibliographies. www.oxfordbibliographies.com/view/document/obo-9780195396577/obo9780195396577-0116.xml 